\title{
Comparison of Amphotericin B Lipid Complex (Abelcet) and Liposomal Amphotericin B (Ambisome) on Rat Kidney: a Morphological Evaluation
}

\author{
Comparasión de la Anfotericina B Complejo Lipídico (Abelcet) y la Anfotericina B Liposomal \\ (AmBisome) en el Riñón de Rata: una Evaluación Morfológica \\ "S. Deniz Mutluay; ${ }^{* *}$ Pınar Karakas; ${ }^{* * *}$ Yesim Tasova; ${ }^{* * * *}$ Ufuk Mete \& ${ }^{* *}$ M. Gülhal Bozkır
}

MUTlUAY, S. D.; KARAKAS, P.; TASOVA, Y.; METE, U. \& BOZKIR, M. G. Comparison of amphotericin B lipid complex (Abelcet) and liposomal amphotericin B (Ambisome) on rat kidney: a morphological evaluation. Int. J. Morphol., 30(2):559-566, 2012.

SUMMARY: The aim of our study was to compare the nephrotoxic effects of liposomal Amphotericin B (Ambisome) and Amphotericin B lipid complex (Abelcet) on rat kidneys at short (14 days) and long term (28 days) treatment applications. Thirty-six male Wistar rats were included and divided into six groups $(n=6)$. Groups 1 and 4 are composed as control groups by administrating intraperitoneal (ip) 0, 9 molar Serum physiologic for a period of 14 and 28 days respectively. Group 2 and 3 are treated with 5 mg/kg Ambisome and 5 $\mathrm{mg} / \mathrm{kg}$ Abelcet for 14 days respectively, Group 5 and 6 are treated with same agents for 28 days respectively. Then, the rats were transcardially perfused, samples were taken from cortex and medulla regions of kidneys. The micrographs of group 1 and 4 were seen as normal. For short term treatment, some morphological changes were seen in proximal tubule cells in group 3 whereas in group 2 the graphs were observed as normal. However, after long term drug using in group 5 and 6 there were vacuolization, increased lysosomal structures and deep basal folding's into tubular cells lumen. These experiments establish that renal damage were seen in short and long term use of Abelcet and long term use of Ambisome.

KEY WORDS: Amphotericin B lipid formulations; Rat kidney; Nephrotoxicity; Ultrastructure.

\section{INTRODUCTION}

Invasive fungal infections have increasingly become a major cause of morbidity and mortality in immunocompromised patients like transplants, chemotherapy and AIDS (Hiemenz \& Walsh, 1998; Bodey, 1988; Hiemenz \& Walsh, 1996; Dismukes, 1988; Annassie, 1992). Amphotericin B is a natural antibiotic belonging to the polyene group, isolated in 1955 from a strain of the actinomycete streptomyces nodosus and it is a key agent in the management of serious systemic fungal infections. Due to its broad spectrum of activity with minimal development of resistance, conventional Amphotericin B has been used in the treatment of invasive fungal infections since 1960's (Hiemenz \& Walsh, 1996; Gallis et al., 1990; Walsh \& Dixon, 1989; Denning \& Stevens, 1990; Tollemar \& Ringdén, 1995). However, Amphotericin B has been introduced clinically, a number of acute and chronic toxicities have made the treatment with this drug difficult for patients to tolerate. Infusion related reactions such as rigors, fever and chills are common (Hiemenz \& Walsh, 1998). Moreover, it has been reported that nephrotoxicity is the most common serious adverse effect of Amphotericin B (Gallis et al.; Walsh \& Dixon; Denning \& Stevens; Tollemar \& Ringdén; Doubek et al., 2005; Mayer et al., 2002; Seabury \& Dascomb, 1960). Even in the setting of maximally tolerated doses of Amphotericin $B$ is frequently fails to control invasive fungal infections, especially in the immunocompromised host. Furthermore mortality is high for neutropenic patients with invasive aspergillosis despite therapy (Hiemenz \& Walsh, 1998, Walsh \& Dixon; Denning \& Stevens).

Amphotericin B is a highly lipophilic drug and in the 1980's it was effectively incorporated with lipids to form liposomes or the lipid based structures (Tollemar \& Ringdén; Utz, 1964; Miller \& Bates, 1969). Three lipid formulations of Amphotericin B are available, which increases the therapeutic index by decreasing the toxicity (Hiemenz \&

Health College of Adana, Çukurova University, Adana, Turkey.

** Faculty of Medicine, Department of Anatomy, Çukurova University, Adana, Turkey.

**** Faculty of Medicine, Department of Infectious Diseases, Çukurova University, Adana, Turkey.

${ }^{* * * * *}$ Faculty of Medicine, Department of Histology-Embryology, Çukurova University, Adana, Turkey. 
MUTLUAY, S. D.; KARAKAS, P.; TASOVA, Y.; METE, U. \& BOZKIR, M. G. Comparison of amphotericin B lipid complex (Abelcet) and liposomal amphotericin B (Ambisome) on rat kidney: a morphological evaluation. Int. J. Morphol., 30(2):559-566, 2012.

Walsh, 1996). These lipid-based formulas of Amphotericin $\mathrm{B}$ are as follow; Amphotericin B lipid complex (ABLC), liposomal Amphotericin B (L-AMB) and Amphotericin B colloidal dispersion (ABCD). These lipids based on to have less nephrotoxic effects than conventional Amphotericin B even at higher doses and they are in the early stages of clinical trials (Doubek et al.; Prentice et al, 1997; White et al., 1998). Meanwhile, Sun et al. (2009) declared that lipid formulations of Amphotericin B are independently associated with less mortality compared with Amphotericin B deoxycholate. Prior studies were shown that there have been better tolerance of these formulations, but no effectual data exist regarding the comparison of ultrastructural effects of Amphotericin B lipid complex (ABLC) and liposomal Amphotericin B (L-AMB) in kidney.

Therefore, the present study was undertaken to investigate morphologically the effects of administration of two separate Amphotericin B lipid formulations- Liposomal Amphotericin B (L-AMB, Ambisome) and Amphotericin lipid complex (ABLC, Abelcet) on rat kidney at short and long term application periods.

\section{MATERIAL AND METHOD}

Thirty- six male Wistar rats (250-300g) were obtained from the Experimental Animal Center in Çukurova University, in Adana in this study. This study was approved by the Animal Care Committee and Ethics Committee of Çukurova University. The animals were housed at an average ambient temperature of $21 \pm 2^{\circ} \mathrm{C}$ under a $12 \mathrm{~h}$ light $/ 12 \mathrm{~h}$ dark cycle and food and water were provided ad libitum.

The chemicals used in this paper are Liposomal Amphotericin B (Ambisome, Erkim Inc; 50mg/kg), Amphotericin B lipid complex (Abelcet, Onko Inc; 100 mg/ $\mathrm{kg}$ ). The animals were divided into 6 groups each including six rats:

Group 1: Rats were injected $9 \%$ serum physiologic ip for 14 days and saved as control group.

Group 2: Rats were administered $5 \mathrm{mg} / \mathrm{kg}$ ambisome ip for 14 consecutive days.

Group 3: Rats were injected ip $5 \mathrm{mg} / \mathrm{kg}$ abelcet for a period of 14 days.

Group 4: Rats were administered with $9 \%$ serum physiologic for 28 days and saved as control group.

Group 5: Rats were injected ip with $5 \mathrm{mg} / \mathrm{kg}$ ambisome for 28 days

Group 6: Rats were injected ip $5 \mathrm{mg} / \mathrm{kg}$ abelcet for a period of 28 days.
After 14 and 28 days drug administration, the rats were deeply anesthetized with ksilazin $(10 \mathrm{mg} / \mathrm{kg})$ and ketamin $(80 \mathrm{mg} / \mathrm{kg})$ and transcardially perfused with 250 $\mathrm{ml} 4 \%$ paraformaldehyde. From each kidney, the tissue samples were taken from the cortex and medullar regions which were $1 \mathrm{~mm} 3$ thick. The tissues were immediately fixed in 5\% glutaraldehyde buffered at $\mathrm{pH} 7.4$ with Millonig phosphate buffer for four hours, postfixed in $1 \%$ osmic acid for two hours, and embedded in araldite. Ultrathin sections were obtained from selected areas, stained with uranyl acetate and lead citrate, and examined with a Zeiss EM 900 transmission electron microscope.

\section{RESULTS}

We addressed the ultrastructural effects of administrating Amphotericin B lipid complex (ABLC) and liposomal amphotericin $\mathrm{B}$ (L-AMB) on rat kidney in the short and long time period.

\section{Electron Microscopic Findings}

Groups 1 and 4 (Control groups): There were no apparent damages in glomerular structures and renal tubules. The spherical and elongated mitochondria were normal appearance in the tubular epithelial cells. Endoplasmic reticulum cisternae, small vacuoles and lysosomes were located between them.

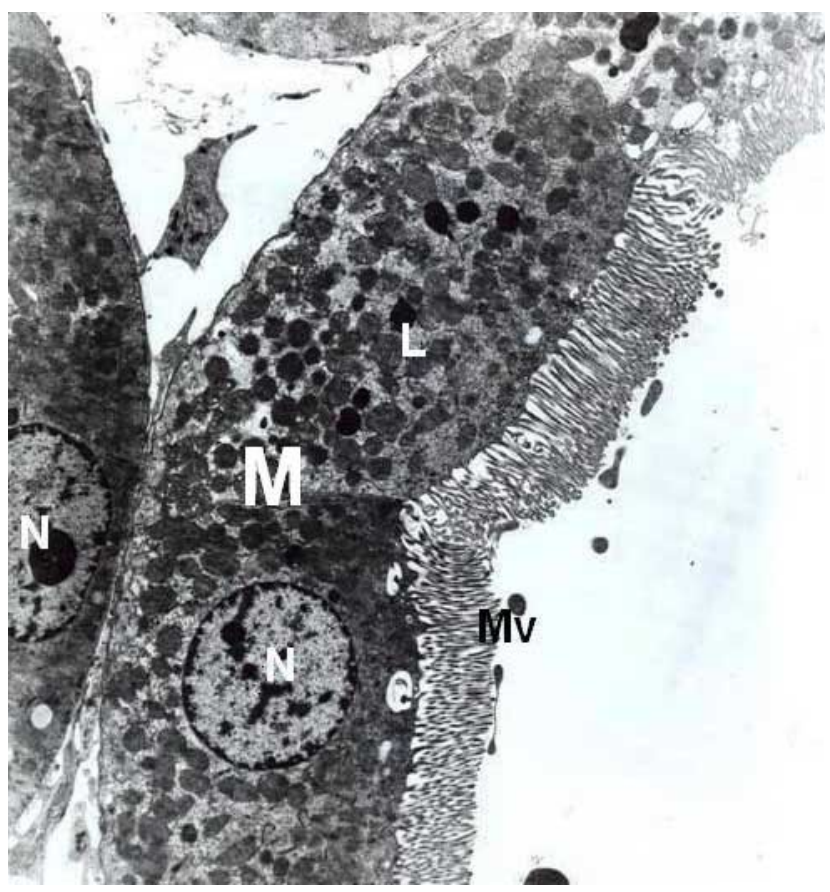

Fig. 1. Control groups, normal proximal convoluted tubule. Nucleus $(\mathrm{N})$, mitochondria (M), lysosomes (L), brush border (BB). X6300. 

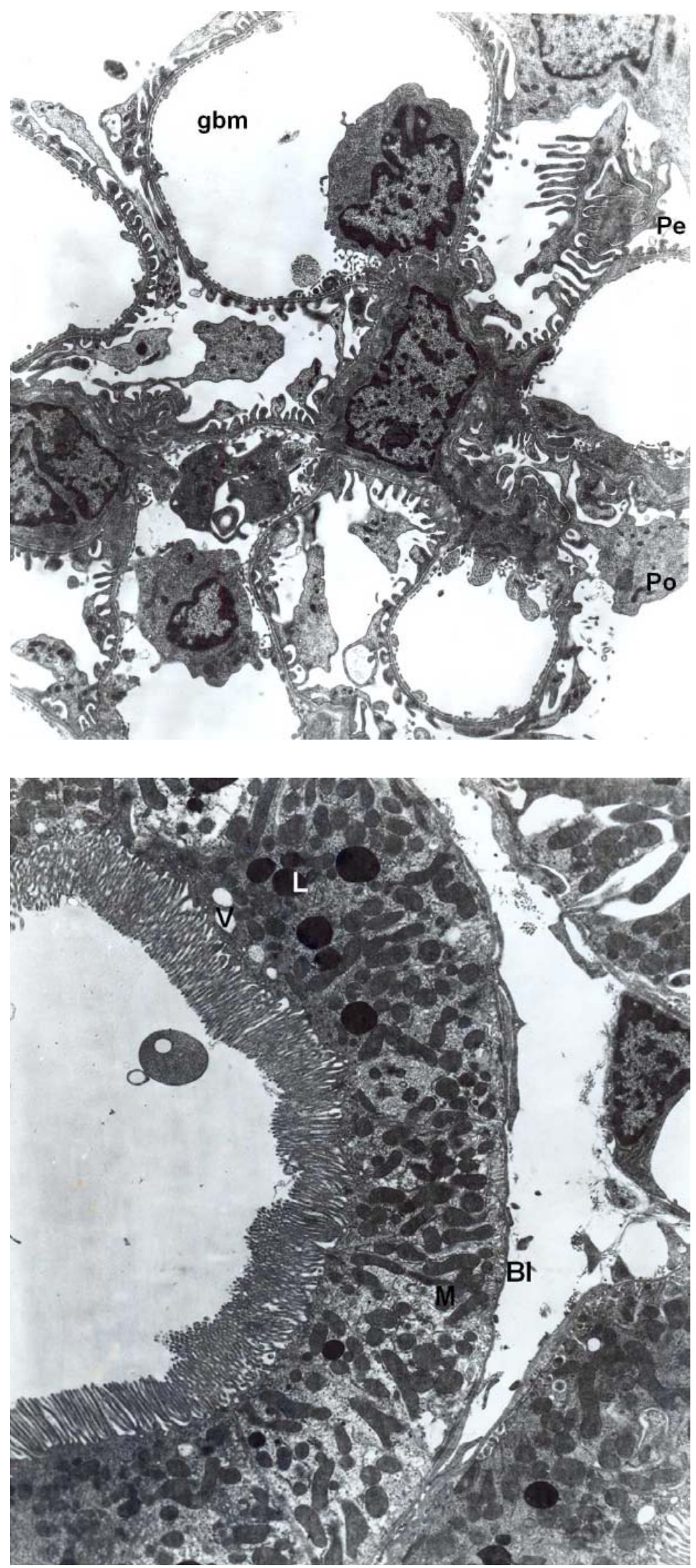

Fig. 2. Control group, normal glomerulus are seen. Podocytes $(\mathrm{Po})$, pedicles $(\mathrm{Pe})$, glomerular basement membrane (GBM). X8100.

High, thin and parallel microvilli were observed on the apical surface of epithelial cells of tubules (Fig. 1). Moreover, the ultrastructural examination revealed normal glomerular basement membrane and normal foot process organization (Fig. 2).

Group 2 (treated with Ambisome for 14 days): Tubular cells appeared nearly normal. The distribution, size and shape of mitochondria and endoplasmic reticulum were normal both in proximal and distal tubular cells (Figs. 3 and 4). Glomerular structures and basement membrane were seen normal as in control groups.

Group 3 (treated with Abelcet for 14 days): Epithelial cells of proximal and distal tubules were nearly normal. Nucleus, mitochondria, endoplasmic reticulum were all normal in morphological appearance. Moreover, on apical cytoplasm lots amount of lysosomes and different size of vacuolar structures were exhibited (Fig. 5). In some cells, vacuolar structure was increased and lytic areas were also seen in cytoplasm (Fig. 6). Tubular and glomerular basement membranes were normal.

\section{Group 5 (treated with Ambisome for 28 days):}

Vacuolar structures and lysosomes were increased in proximal tubule epithelial cells. Most of these cells, the basal laminae were seen in normal thicknesses; in some proximal tubule cells deep basal foldings were seen (Fig. 7). Some of the cells made protrusion into the lumen. In these cells, increased lysosomes were also seen (Fig. 8). In distal tubule cells, same ultrastructural changes exhibited like proximal tubule cells. In these cells deep basal foldings were seen. Moreover, huge of vacuolar structures were also found. These different shaped vacuolar structures were rounded with membrane whether, in cytoplasm place to place they were incorporated to made large vacuoles (Fig. 9). Glomerular capillary endothelial cells and glomerular basement membrane were shown in normal histological structures.

Fig. 3. Group 2, proximal convoluted tubule are seen normal as in control groups. Mitochondria (M), lysosomes (L), brush border (BB), basal lamina (Bl). X6300. 

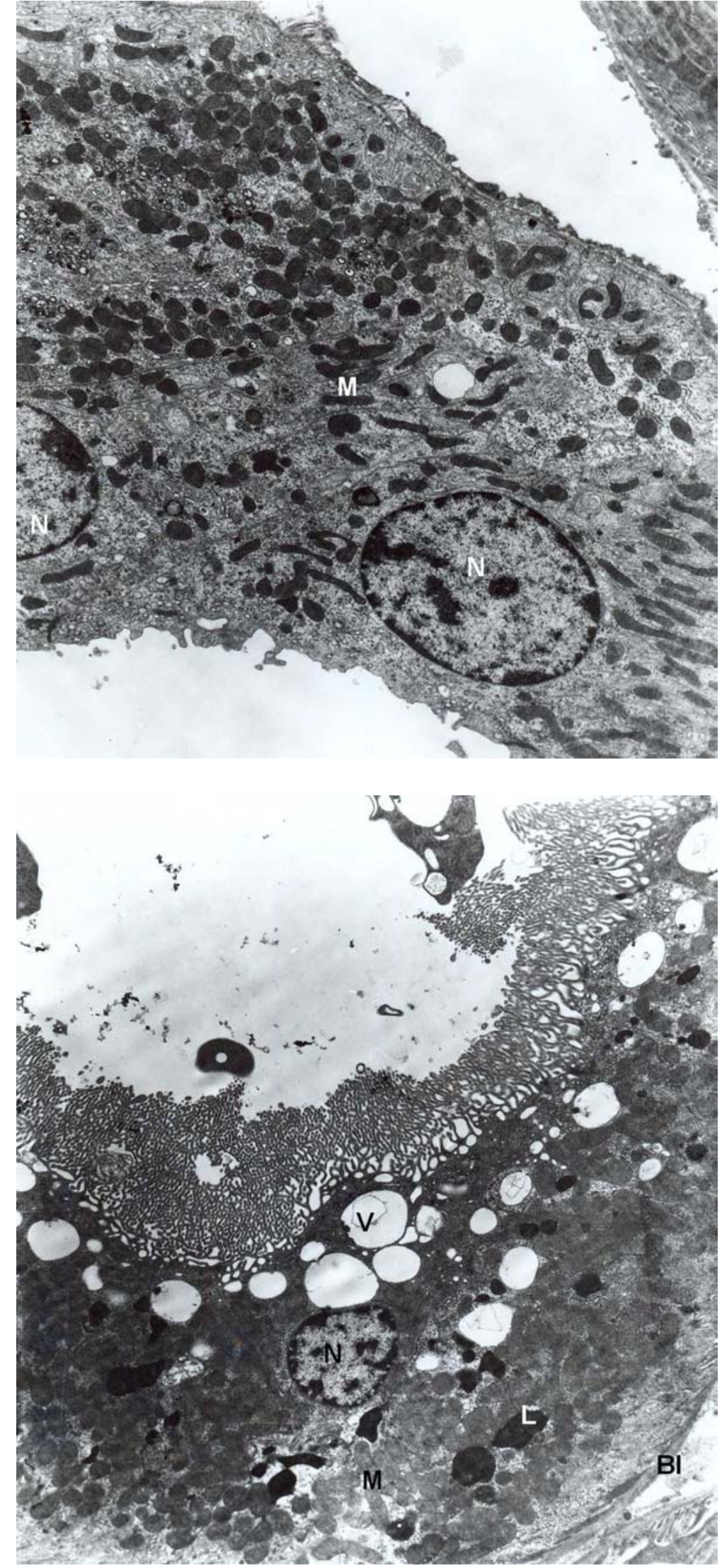

Fig. 4. Group 2, distal tubule are seen normal. Nucleus (N), mitochondria (M). X8100.

Group 6 (treated with Abelcet for 28 days): In proximal tubule epithelial cells, vacuolar structures were increased prominently. These cells were rich of mitochondria and lysosomes. The spherical and elongated mitochondria were abundant. There was an increase in the spaces between the interdigitations (Fig. 10). In distal tubule epithelial cells, nucleus and the organelles were shown in normal ultrastructure (Fig. 11). In glomerular capillary endothelial cells and glomerular basement membrane were shown in normal histological properties.

\section{DISCUSSION}

In this paper, the renal toxicity profiles of liposomal Amphotericin B (Ambisome) and Amphotericin B lipid complex (Abelcet) administrating following short and long time periods have been described in experimental animals. The results of these experiments indicate that, both drug administrations cause some morphological changes in the distal and proximal convoluted tubule cells in rats.

Classical amphotericin B has disrupted the function of tubular and vascular smooth muscle cells by changing the permeability of cell membranes and leads to various tubular transport defects and vasoconstriction on blood vessels (Doubek et al.; Sun et al.; Larabi et al., 2004;Deray, 2002; Wasan et al., 1990; Krejcírová et al., 2004). It has been established that lipid based amphotericin B is responsible from transforming cell morphology, function and intracellular transport system by the toxic effect of the amphotericin B molecule (Doubek et al.; Sawaya et al., 1995). In our study, the distribution, size and shape of mitochondria, basal lamina and glomerulus were seen normal both in proximal and distal tubular cells after short and long-term administration of Ambisome (Figs. 3 and 4) and Abelcet

Fig. 5. Group 3, proximal convoluted tubule. Different size of vacuolar structures (V), lysosomes (L), nucleus (N), brush border (BB). X6300. 

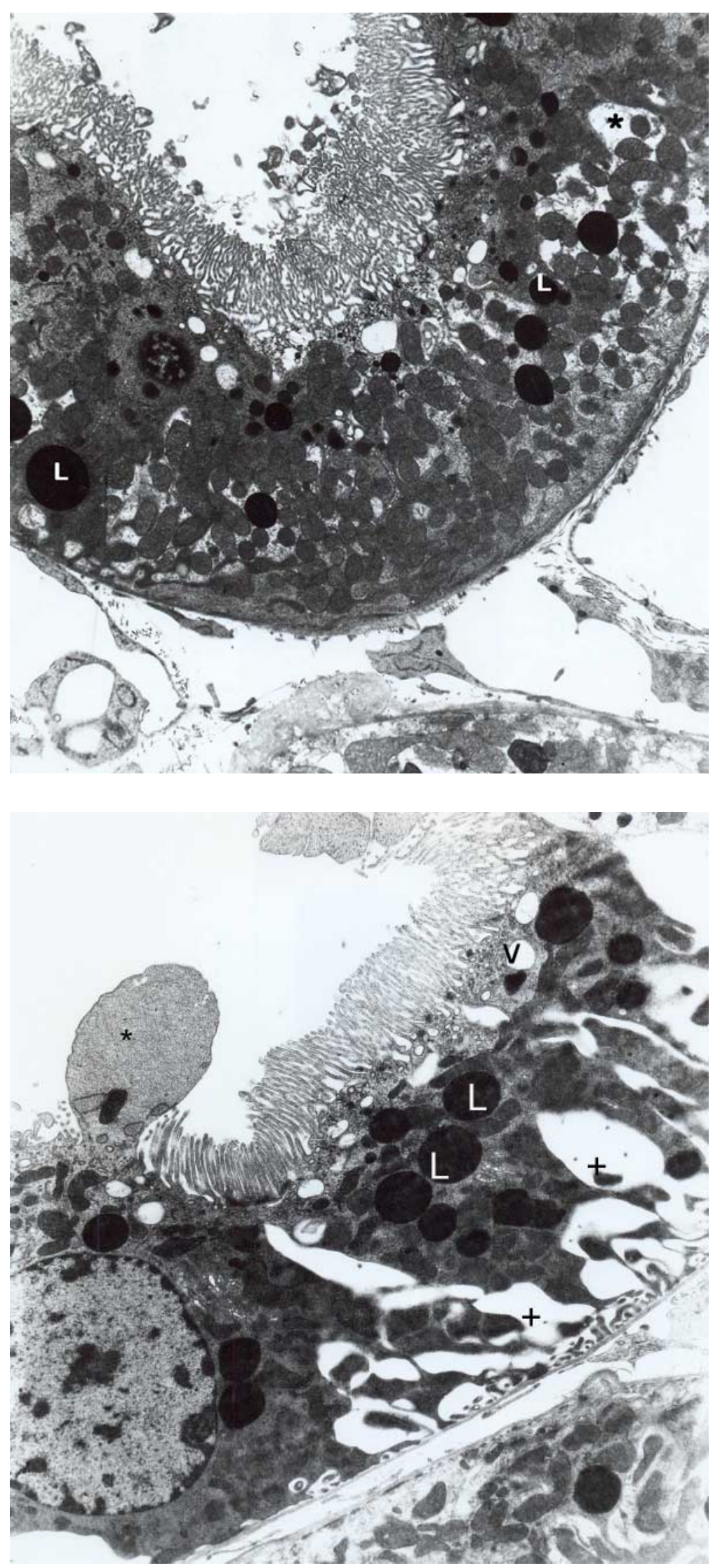

Fig. 6. Group 3, proximal convoluted tubule. Lytic areas (asterix) are seen. Vacuoles (V), lysosomes (L), brush border (BB). X6300.

compared to control groups (Figs. 1 and Fig 2 ). Doubek et al. colleagues reported morphologic damages on kidney tubules and in glomerulus. They indicate that despite the severe morphological tubular damage, the glomerular defect is functional. In addition, it was determined that tubular destruction in the cell cytoplasm with small vacuolar structures and an increase in densities of peroxisomes (Doubek et al.; Lauschová et al., 2004). In our experiments as well as glomerular structures and basement membrane were seen normal in both drugs after 14 and 28 day usage as like in control groups (Fig. 2). However, some morphological changes on apical cytoplasm like lots number of lysosomes, lytic areas and vacuolar structures in tubuler epithelium in rat kidneys have been shown after in short-term use of Abelcet (Figs. 5 and Fig. 6). By the way, rats receiving short-term Ambisome showed near normal tubular cells (Figs. 3, 4). On the other hand after long-term Ambisome and Abelcet administration vacuolar structure has been shown increased (Figs. 9 and 10). It is thought that this vacuolar structure considered due to additional dilatations of endoplasmic reticulum in kidney tubule cells (Mihatsch et al., 1998; Duncan et al., 1986). Basal folding into the lumen has been shown also increased after long term usage of both drug administrations. Moreover, some of the cells made protrusion into the lumen (Figs. 7-10). Since, amphotericin B alters the transport system of cell membranes, it can be speculated that the basal folding may represent an increase in the surface area of the basal plasma membranes for the enhancement of the membrane transport of the proximal tubule cells (Sawaya et al.). If a cell exposed to a toxic substance; harmful substances accumulate in the cell and breaks down the cell metabolism. It is known that, all of these harmful substances which are accumulated in cytoplasm are a result

Fig. 7. Group 5, proximal convoluted tubule. Cytoplasmic protrusion (arrow), deep basal folding (asterix) are striking. Nucleus (N), lysosomes (L). X10100. 

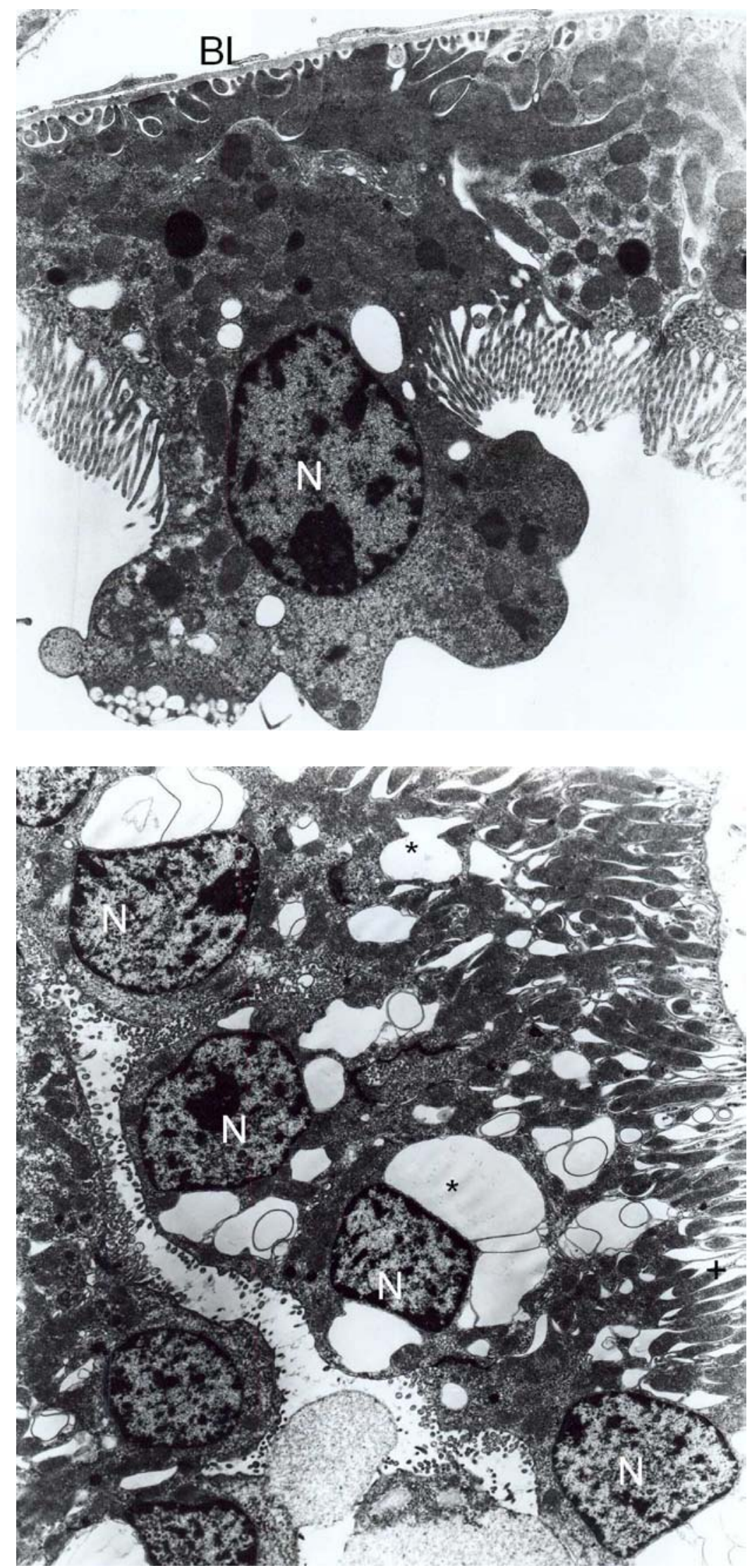

Fig. 8. Group 5, proximal convoluted tubule. Cytoplasmic part contained nucleus $(\mathrm{N})$ and vacuoles $(\mathrm{V})$ are made protrusion between microvilli (Mv). X12400.

of degeneration of the organelles. These harmful substances are removing from the cell by lysosomes function. So we think that lysosomal structures which are seen in the proximal and distal tubule cells in our investigation are developed due to the effect of amphoterisin B incorporated with lipids, like ambisome and abelcet.

In an experimental study it was reported that, proximal tubule epithelial cells were found more sensitive to nephrotoxic influences of classical amphotericin B and colloidal amphotericin B according to distal tubule epithelial cells (Krejcírová et al.). When morphological findings in this paper are taken into consideration, the cell degeneration seen with ambisome using seems to be less severe compared to abelcet using. Furthermore, in our study it was indicated that, after short-term ambisome treatment proximal and distal tubule epithelial cells, nuclei and organelles were observed in normal structure. However, only changes were observed in proximal tubule cells in Abelcet group (Fig. 11). After longterm treatment, vacuolar and lysosomal structures were increased in only proximal tubule cells in abelcet group, but in long term using Ambisome, some morphologic changes were observed in proximal and distal tubules (Figs. 8 and Fig 9). The differences observed in proximal tubule were significantly higher than distal tubules. It can be assumed, that proximal tubule epithelial cells were more sensitive to both formulas than the distal tubule cells. According to these data, it could be thought that lipid formulations of amphotericin B might change the kidney function due to amphotericin B molecule's acute effect.

Fig. 9. Group 5, distal convoluted tubule. Increased vacuoles (V) and deep foldings (asterix) are noticed. X6300. 


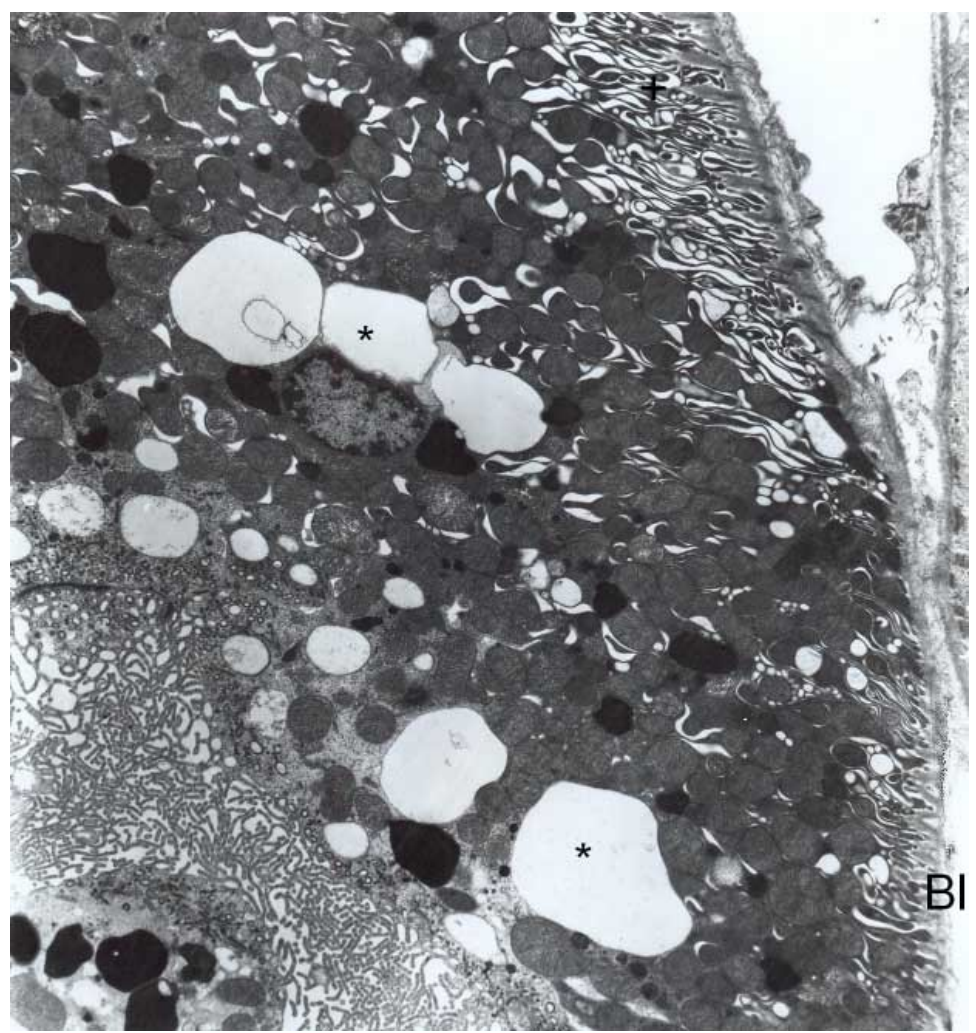

Fig. 10. Group 6, proximal convoluted tubule. Increased vacuoles (V), lysosomes (L), mitochondria (M) and deep foldings (asterix) are seen. X6300.

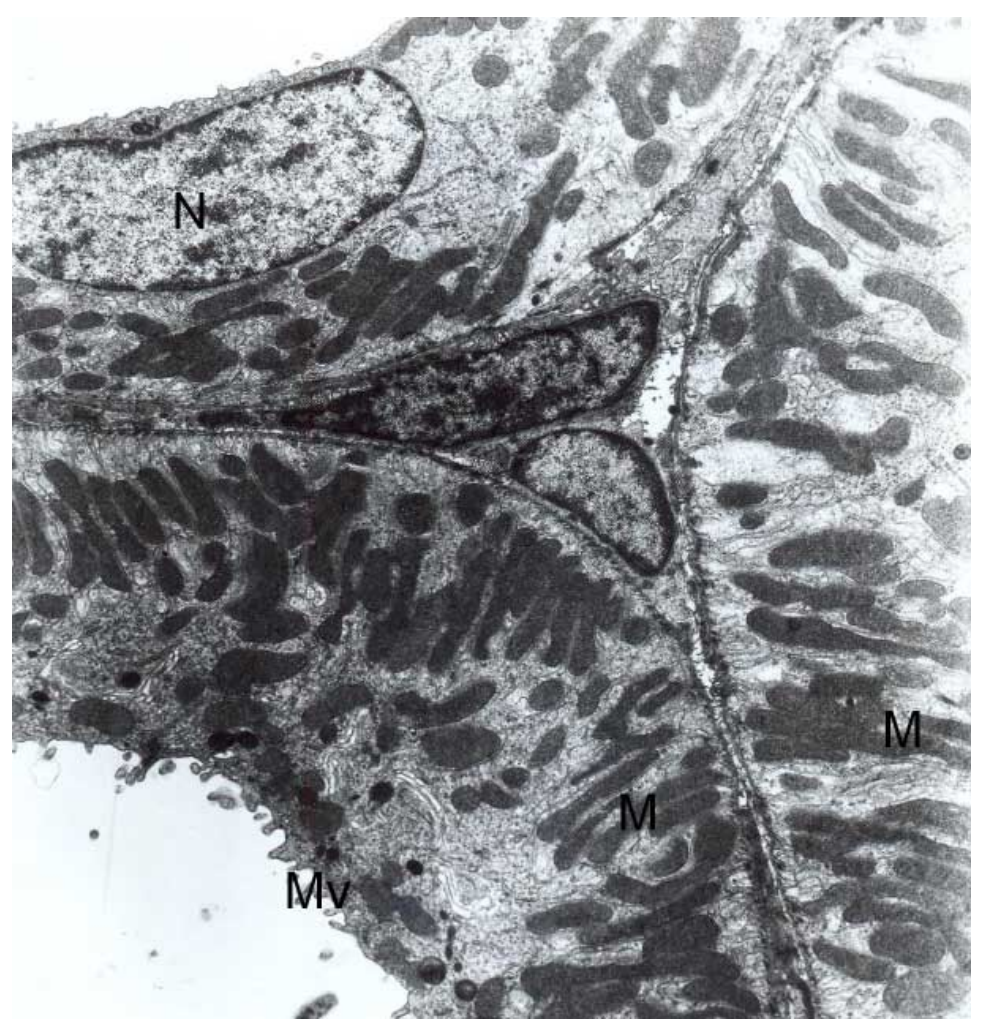

Fig. 11. Group 6, distal convoluted tubule is seen normal appearance. Nucleus (N) and mitochondria (M). x10100.
In summary, the main ultrastructural findings were vacuolization and increasing lysosomes in tubular cells in Abelcet using at short and long time and only after long time use of Ambisome. Thus, our findings pointed out the risk of increased morphological changes due to shortlong term use of the lipid based amphotericin B antifungal agent, Abelcet and long term use of Ambisome. In conclusion, although lipid based amphotericin B agents are effective in invasive fungal infection management, their toxic effects should be kept in mind during long-term usage.

MUTLUAY, S. D.; KARAKAS, P.; TASOVA, Y.; METE, U. \& BOZKIR, M. G. Comparación de la anfotericina B complejo lipídico (Abelcet) y la anfotericina B liposomal (AmBisome) en el riñón de rata: una evaluación morfológica. Int. J. Morphol., 30(2):559-566, 2012.

RESUMEN: El objetivo de nuestro estudio fue comparar los efectos nefrotóxicos de la anfotericina B liposomal (AmBisome) y anfotericina B en complejo lipídico (Abelcet) sobre riñones de ratas, en el tratamiento de aplicación a corto (14 días) y largo plazo (28 días). Fueron incluidas en el estudio 36 ratas Wistar machos, divididas en seis grupos $(n=6)$. Los Grupos 1 y 4 fueron grupos de control mediante la administración intraperitoneal (ip) de 0,9 Molar de suero fisiológico durante un periodo de 14 y 28 días respectivamente. Los Grupos 2 y 3 fueron tratados con $5 \mathrm{mg} / \mathrm{kg}$ de Ambisome y $5 \mathrm{mg} / \mathrm{kg}$ Abelcet durante 14 días respectivamente, y finalmente los grupos Grupos 5 y 6 tratados con los mismos agentes durante 28 días, respectivamente. Luego, las ratas fueron perfundidas vía transcardíaca, y se tomaron muestras de la corteza y la médula renal. Las micrografías de los grupos 1 y 4 se observaron normal. En el tratamiento a corto plazo, algunos cambios morfológicos se observaron en las células del túbulo proximal en el grupo 3, mientras que en el grupo 2 los gráficos se observaron normales. Sin embargo, después de utilizar la droga a largo plazo en los grupos 5 y 6 hubo vacuolización, aumento de las estructuras lisosomales y un profundo plegamiento basal de las células del lumen tubular. Estos experimentos establecen que el daño renal se produce en el uso a corto y largo plazo de Abelcet, y largo plazo de Ambisome.

PALABRAS CLAVE: Anfotericina B formulaciones lipídica; Riñón de rata; Nefrotoxicidad; Ultraestructura. 


\section{REFERENCES}

Annassie, E. Opportunistic mycoses in the immunocompromised host: experience at a cancer center and review. Clin. Infect. Dis., 14(11):S40-53,1992.

Bodey, G. P. The emergence of fungi as major hospital pathogens. $J$. Hop. Infect., 11(A):411-26,1988.

Denning, D. W. \& Stevens, D. A. Antifungal and surgical treatment of invasive fungal aspergillosis: review of 2.121 published cases. Rev. Infect. Dis., 12(6):1147-201,1990.

Deray, G. Ampotericin B nephrotoxicity. J. Antimicrob. Chemother, 49:37-41, 2002.

Dismukes, W. E. Cryptoccocal meningitis in patient with AIDS. J. Infect. Dis., 157(4):624-8, 1988.

Doubek, M.; Mayer, J.; Lauschova, I.; Scher, P.; Krejirova, L.; Horky, D. \& Doubek, J. Comparison effect of amphotericin B desoxycholate and amphotericin B colloidal dispersion on renal functions and renal morphology in rats. Nephrology, 10(1):57-62, 2005.

Duncan, J. I.; Thomson, A. W.; Aldridge, R. D.; Simpson, J. G. \& Whiting, P. Cyclosporine induced renal structural damage: influence of dosage, strain, age and sex with reference to the rat and guinea pig. Clin. Nephrol., 25(1):14-7,1986.

Gallis, H. A.; Drew, R. H. \& Pickard, W. W. Amphotericin B: 30 years of clinical experience. Rev. Infect. Dis., 12(2):308-29,1990.

Hiemenz, J. W. \& Walsh, T. J. Lipid formulations of amphotericin B: Recent Progress and Future Directions. Clin. Infect. Dis., 22(2):13344,1996.

Hiemenz, J. W. \& Walsh, T. J. Lipid formulations of amphotericin B. J. Liposome Research, (4):443-67, 1998.

Krejcírová, L.; Lauschová, I.; Horky, D.; Doubek, M.; Mayer, J. \& Doubek, J. Influence of amphotericin B deoxyholate or amphotericin B colloidal dispersion on renal tubule epithelium in rat. Biomed. Pap. Med. Fac. Univ. Palacky Olomouc Czech Repub., 148(2):2213, 2004.

Larabi, M.; Pages, N.; Pons, F.; Appel, M.; Gulik, A.; Schlatter, J.; Bouvet, S. \& Barratt, G. Study of the toxicity of a new lipid complex formulation of amphotericin B. J. Antimicrob. Chemother., 53:818, 2004.

Lauschová, I.; Krejcírová, L.; Horky, D.; Doubek, M.; Mayer, J. \& Doubek, J. Ultrastructural morphometry of renal tubule epithelium in rats treated with conventional amphotericin B deoxycholate or amphotericin B colloidal dispersion. Acta Vet. Brno., 73:165-9, 2004.

Mayer, J.; Doubek, M.; Doubek, J.; Horky, D.; Sheer, P. \& St?pánek, M. Reduced nephrotoxicity of conventional amphotericin B therapy after minimal nephroprotective measures: Animal experiments and clinical study. J. Infect. Dis., 186(3):379-88, 2002.
Mihatsch, M. J.; Thiel, G. \& Ryffel, B. Histopathology of cyclosporine nephrotoxicity. Transplant. Proc., 20(3):759-71, 1988.

Miller, R. \& Bates, H. J. Amphotericin B toxicity. A follow up report of 53 patients. Ann. Intern. Med., 71:1090-1095, 1969.

Prentice, H. G.; Hann, I. M.; Herbrecht, R.; Aoun, M.; Kvaloy, S.; Catovsky, D.; Pinkerton, C. R.; Schey, S. A.; Jacobs, F.; Oakhill, A.; Stevens, R. F.; Darbyshire, P. J. \& Gibson, B. E. A randomized comparison of liposomal versus conventional amphotericin B for the treatment of pyrexia of unknown origin in neutropenic patients. Br. J. Haematol., 98(3):710-8, 1997.

Seabury, J. H. \& Dascomb, H. E. Experience with amphotericin B. Ann. NY. Acad. Sci., 89:202-220, 1960.

Sawaya, B. P.; Briggs, J. P. \& Schnermann, J. Amphotericin B nephrotoxicity: The adverse consequences of altered membrane properties. J. Am. Soc. Nephrol., 6(2):154-64, 1995.

Sun, H. Y.; Alexander, B. D.; Lortholary, O.; Dromer, F.; Forrest, G. N.; Lyon, G. M.; Somani, J.; Gupta, K. L.; del Busto, R.; Pruett, T. L.; Sifri, C. D.; Limaye, A. P.; John, G. T.; Klintmalm, G. B.; Pursell, K, Stosor, V, Morris, M. I.; Dowdy, L. A.; Munoz, P.; Kalil, A. C.; Garcia-Diaz, J.; Orloff, S.; House, A. A.; Houston, S.; Wray, D.; Huprikar, S.; Johnson, L. B.; Humar, A.; Razonable, R. R.; Husain, S. \& Singh, N. Lipid formulations of amphotericin B significantly improve outcome in solid organ transplant recipients with central nervous system cryptococcosis. Clin. Infect. Dis., 49:1721-8, 2009.

Tollemar, J. \& Ringdén, O. Lipid formulations of Amphotericin B. Less toxicity but at what economic cost? Drug Saf., 13(4):207-18,1995.

Utz, J. Amphotericin B toxicity: Introduction. Ann. Intern. Med., 61:3348,1964 .

Walsh, T. J. \& Dixon, D. M. Nasocomial aspergillosis: environmental microbiology, hospital epidemiology, diagnosis and treatment. Eur. J. Epidemiol., 5(2):131-42,1989.

Wasan, K. M.; Vedel, K.; Lopez, B. G. \& Luck, D. R. Pharmacokinetics, tissue distribution and toxicity of free liposomal amphotericin B in diabetic rats. J. Infect. Dis., 161:562-6, 1990.

White, M. H.; Bowden, R. A.; Sandler, E. S.; Graham, M. L.; Noskin, G. A.; Wingard, J. R.; Goldman, M.; van Burik, J. A.; McCabe, A.; Lin, J. S.; Gurwith, M. \& Miller, C. B. Randomized, double-blind clinical trial of amphotericin B colloidal dispersion versus amphotericin B in the empirical treatment of fever and neutropenia. Clin. Infect. Dis., 27:296-302, 1998.

Correspondence to:

Pınar Karakas, Assoc. Prof. Dr., M.D.

Çukurova University

Faculty of Medicine

Department of Anatomy, 01330, Adana

TURKEY

Email: pkarakas@cu.edu.tr

Received: 29-11-2011

Accepted: 10-01-2012 